Hydrol. Earth Syst. Sci., 17, 2171-2183, 2013

www.hydrol-earth-syst-sci.net/17/2171/2013/

doi:10.5194/hess-17-2171-2013

(C) Author(s) 2013. CC Attribution 3.0 License.

\title{
Characterization of groundwater dynamics in landslides in varved clays
}

\author{
J. E. van der Spek, T. A. Bogaard, and M. Bakker \\ Water Resources Section, Faculty of Civil Engineering and Geosciences, Delft University of Technology, P.O. Box 5048, \\ 2600 GA Delft, the Netherlands
}

Correspondence to: T. A. Bogaard (t.a.bogaard@tudelft.nl)

Received: 6 December 2012 - Published in Hydrol. Earth Syst. Sci. Discuss.: 10 January 2013

Revised: 6 May 2013 - Accepted: 7 May 2013 - Published: 7 June 2013

\begin{abstract}
Groundwater dynamics may play a significant role in landslides. A detailed model is developed of the groundwater dynamics in landslides in varved clays in the Trièves area in the French Alps. The varved clays consist of a sequence of alternating silt and clay layers, covered by a colluvium layer and intersected by fissures. The hydraulic conductivity of the clay layers is negligible compared to the silt layers. It is conceptualized that fissures form a hydraulic connection between the colluvium and the varved clays. Groundwater recharge flows through the colluvium into the fissures, where water is exchanged horizontally between the fissure and the silt layers of the varved clays. Groundwater flow in the colluvium is simulated with the Boussinesq equation, while flow in the silt layers of the varved clays is simulated with the Richards equation. Longitudinal outflow from the fissure is simulated with a linear-reservoir model. Scattered data of relatively short monitoring periods is available for several landslides in the region. A good similarity between observed and simulated heads is obtained, especially when considering the lack of important physical parameters such as the fissure width and the distance between the monitoring point and the fissure. A simulation for the period 19592004 showed some correlation between peaks in the simulated heads and the recorded occurrence of landslides, while the bottom of the varved clays remained saturated during the entire simulation period.
\end{abstract}

\section{Introduction}

The hydrological mechanisms taking place in landslides are often not investigated extensively, whereas their importance is frequently recognized (e.g. Reid and Iverson, 1992; Iverson, 2000; Wilkinson et al., 2002; Lindenmaier et al., 2005; Schulz et al., 2009; Wienhöfer et al., 2010; Bogaard et al., 2012). As a result, the effects of changes in climate or land use on landslide occurrence are difficult to predict (e.g. Buma and Dehn, 1998; Van Beek, 2002; Malet et al., 2005; Van Westen et al., 2006). Water flow through fissures in landslides is an example of a hydrological process that is discussed frequently, but rarely quantified (Van Beek and Van Asch, 1999; Krzeminska et al., 2012). Landslides are commonly conceptualized as heterogeneous, cascading systems, which are difficult to simulate with standard hydrological models (e.g. Uchida et al., 2001; Van Asch et al., 2007). To make matters worse, there is often a significant lack of subsurface data.

In the Trièves region in the French Alps, varved clays are highly susceptible to landslides (Giraud et al., 1991). At least $15 \%$ of the area covered by the varved clays is considered to be unstable (Jongmans et al., 2009). Displacement velocities range from several millimeters to several centimeters per year, with the risk that the velocities may suddenly increase and lead to catastrophic failure. Infiltration of precipitation is the most important triggering mechanism for landslides in varved clays, as increased pore water pressure on the slip plane results in a reduction in stability (Van Asch et al., 1996, 2007; Van Genuchten and Van Asch, 1988; Van Genuchten, 1989; Vuillermet et al., 1994). 
Varved clays consist of alternating laminae of silt and clay. The hydraulic conductivity of the clay laminae is extremely low, while that of the silt laminae is larger. The hydrogeology of the varved clays is strongly influenced by fissures that develop as a result of displacement. The hydrogeological system may be described as a cascading system, where fluxes from surface layers interact with the underlying varved clays through fissures (Van Genuchten and Van Asch, 1988; Nieuwenhuis, 1991; Van Asch et al., 1996). Prediction of displacements in varved clay landslides requires a better understanding of the groundwater dynamics in these complex systems.

The objective of this paper is to present an approach for the quantification of groundwater dynamics in varved clays and relate these dynamics to observed landslide movements. The presented approach is applied to study the water pressure propagation in varved clays, the influence of fissures, and the influence of the perched groundwater in the colluvium layer. The structure of this paper is as follows. First, a conceptual hydrological model is presented for landslides in varved clays, based on the hydrological system of the Trièves (Sect. 2). The conceptual model is translated into a mathematical model in Sect. 3 and is implemented in a computer program to simulate the groundwater dynamics. The main factors influencing groundwater dynamics are discussed in Sect. 4 and the results of the model calibration are described in Sect. 5. Groundwater dynamics are simulated for a $46 \mathrm{yr}$ period and are compared to reported landslide movements in Sect. 6, followed by discussion and conclusion sections.

\section{Conceptual hydrological model of Trièves area}

Varved clays are characteristic for the geology of the Trièves area in the French Alps. These clays were deposited in a glacial lake of around $300 \mathrm{~km}^{2}$ during the last glacial or Würm period (30000-10000 yr ago). The lake developed when the Isère glacier blocked the valleys of the river Drac and its tributaries (Fig. 1) (Van Genuchten, 1989; Giraud et al., 1991).

Varved clays are sediments with alternating laminae of silty and clayey material of $\mathrm{mm}$ to $\mathrm{cm}$ scale (Van Genuchten, 1989; Giraud, 1988; Giraud et al., 1991; Huff, 1989; Vuillermet et al., 1994). The finer grained clay layers were deposited when the lake surface was frozen. The coarser grained silt layers were deposited during warmer periods. Huff (1989) measured silt to clay ratios of 0.23 to 1.4 in the Trièves area. The thickness of the varved clays varies from 0 to $200 \mathrm{~m}$ over short distances due to the irregular subsurface. The varved clays were deposited on top of carbonate bedrock and are covered by a colluvium layer $1-4 \mathrm{~m}$ thick. The colluvium layer is relatively permeable compared to the varved clays (Van Asch et al., 1996). The average hydraulic conductivity of varved clay deposits is highly anisotropic due to their horizontally layered texture; the permeability of the

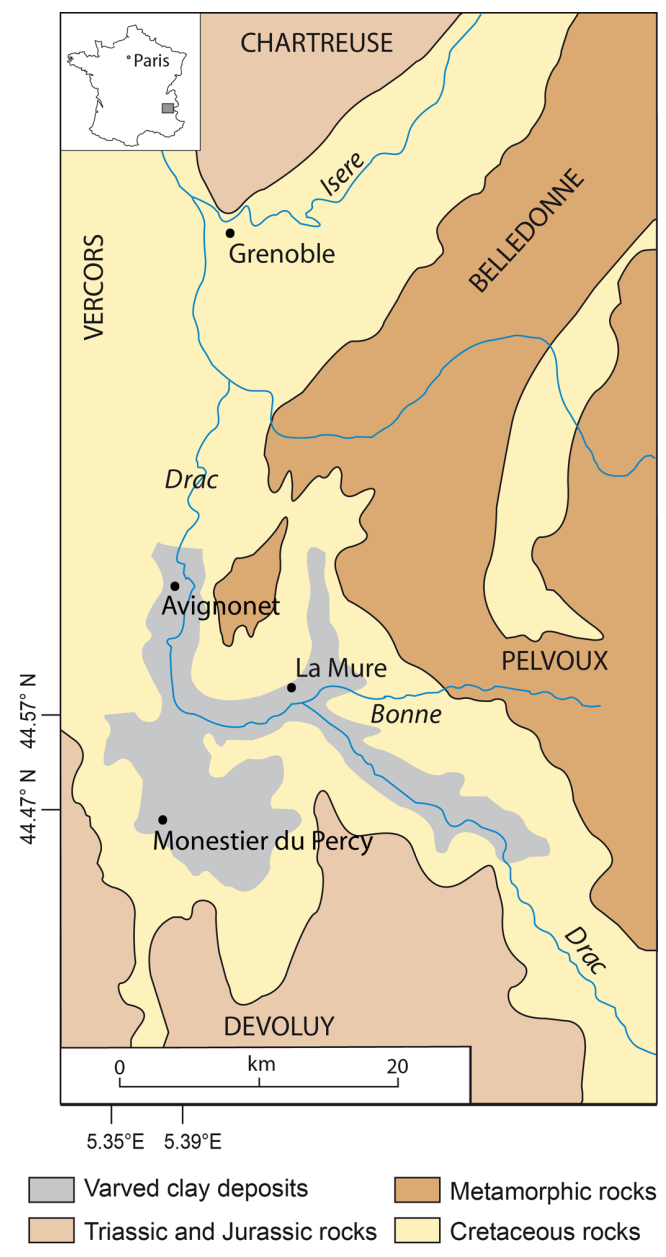

Fig. 1. Geology of the Trièves area and locations of landslides used in this study.

clay laminae is negligible compared to the permeability of the silt layers. Slopes in varved clays are unstable at gradients exceeding $8-10^{\circ}$ (Giraud et al., 1991).

Numerous landslides have occurred in the Trièves area in the last century. The landslides are rotational or translational slides with slip surfaces at depths ranging from relatively shallow (4-8 m) to deeper (20-40 m) (Van Asch et al., 1996). The surface areas of the landslides vary, from almost $10^{5} \mathrm{~m}^{2}$ (Monestier du Percy landslide, Giraud et al., 1980) to $10^{6} \mathrm{~m}^{2}$ (Avignonet landslide, Jongmans et al., 2009). The movement induces vertical fissures (Bièvre et al., 2012; Nieuwenhuis, 1991), which are several meters long (Van Genuchten, 1989) and mostly parallel to the contour lines (Bièvre et al., 2012; Nieuwenhuis, 1991). The fissures reach different depths and are connected to the slip surfaces of the landslides (Van Asch et al., 1996; Bièvre et al., 2012; Nieuwenhuis, 1991; Vuillermet et al., 1994). The fissure density varies over the area as well as within the landslides. For example, in a landslide near La Mure most fissures are found in the downslope part (Van Genuchten, 1989). In the Avignonet landslide the 


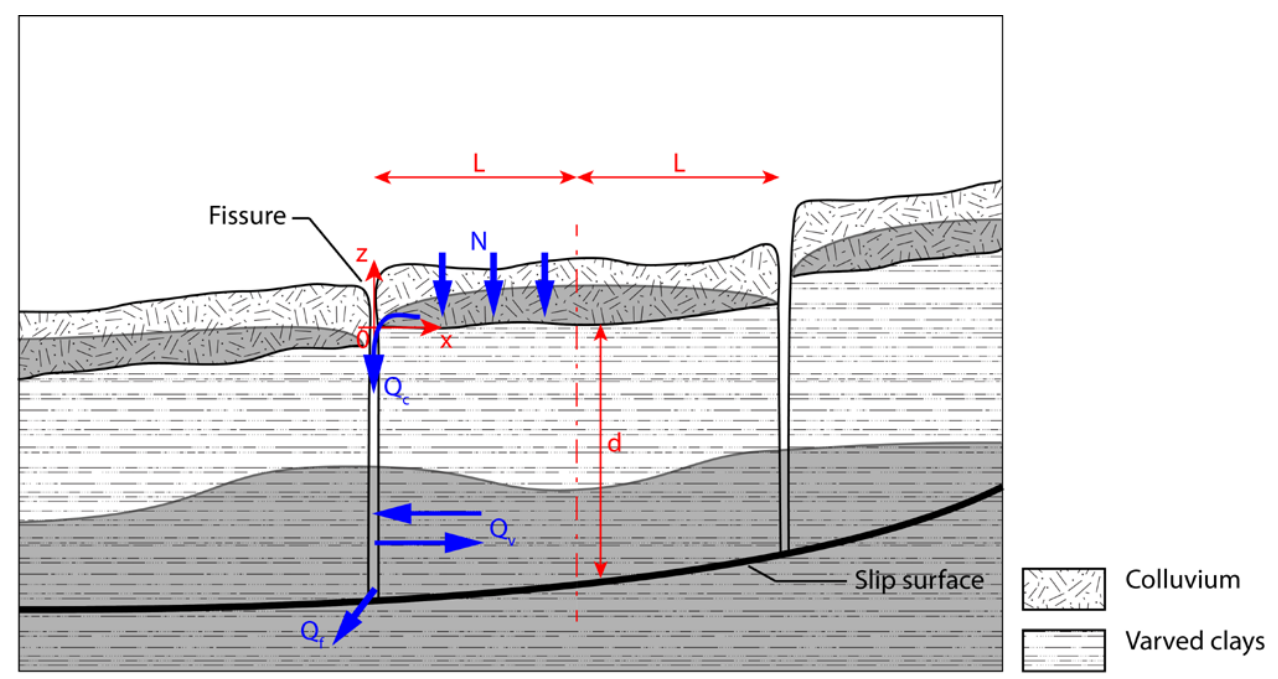

Fig. 2. Conceptual cross section of the varved clay landslides and the fluxes between the subsystems: areal recharge $(N)$, outflow from the colluvium into the fissure $\left(Q_{\mathrm{c}}\right)$, flow from the fissure into the varved clays $\left(Q_{\mathrm{v}}\right)$ or vice versa, and outflow from the fissure into the fissure network $\left(Q_{\mathrm{f}}\right)$ normal to the plane of flow.

fissure density is largest in parts where the slope angle is relatively large (Bièvre et al., 2012). Field observations by Van Asch et al. (1996) indicated that the distance between 10$20 \mathrm{~m}$ deep fissures is about $40 \mathrm{~m}$; fissures with depths and distances of only a few meters are found as well (Nieuwenhuis, 1991). The fissures are partly filled with clay and silt and are not always visible at the land surface. Some of the fissures are connected across the contour lines which allows downslope drainage of the landslide through the fissure network (Nieuwenhuis, 1991).

A schematized cross section of part of a landslide in varved clays is shown in Fig. 2. The groundwater dynamics in varved clay landslides can be summarized as follows (Van Asch et al., 1996; Vuillermet et al., 1994). Precipitation infiltrates into the colluvium layer, where perched groundwater develops above the varved clays. Water flows from the colluvium into the vertical fissures and infiltrates horizontally into the silt layers of the varved clays. Conversely, water drains from the silt layers into the fissures when the head in the silt layers exceeds the head in the fissures. Vertical flow passing the clay laminae in the varved clays is considered negligible. The landslides are drained in downslope direction through a system of connected fissures, normal to the plane of flow shown in Fig. 2. Surface runoff directly into the fissures is neglected.

The stability of a landslide is a direct function of infiltration from fissures into the silt laminae of the varved clays at the level of the slip surface. Preferential flow along the slip surface is assumed to be negligible. Not all fissures are connected to the slip surface. Shallow fissures mainly influence the pore water pressure in the upper part of the varved clays, and the infiltration into and drainage of the colluvium. The
Table 1. Dimensions of the two standard systems.

\begin{tabular}{lll}
\hline System & $L$ & $d$ \\
\hline Large & $20 \mathrm{~m}$ & $20 \mathrm{~m}$ \\
Small & $5 \mathrm{~m}$ & $5 \mathrm{~m}$ \\
\hline
\end{tabular}

pore water pressure at the slip surface may be influenced indirectly, due to a change in the inflow into deeper fissures. In this paper the hydrological system is approximated as shown in Fig. 2, but with all fissures at one location reaching the same depth.

The distance between two fissures is called $2 L$ and the depth of a fissure is called $d$ (Fig. 2); both vary over the area. The exact distance and depth at the measurement locations are unknown. Two standard systems are considered: one with a large fissure distance and depth, referred to as the large system, and one with a small fissure distance and depth, referred to as the small system (Table 1). Model simulations are presented for these two standard systems and compared to head observations from monitored landslides using the standard system that is most appropriate.

\section{Mathematical model}

The conceptual model consists of two subsystems: the colluvium and the varved clays (Fig. 2). The fissure connects both systems; the head in the fissure acts as a boundary condition for each system. The system between two fissures is approximated as horizontal, and horizontally symmetrical. The $\mathrm{x}$ axis runs from the fissure $(x=0)$ to the center between two 
fissures $(x=L)$ (Fig. 2). Flow in the colluvium and varved clays is approximated to occur in a vertical cross section.

Flow in the colluvium is written in terms of the hydraulic head $h_{\mathrm{c}}[\mathrm{L}]$ in the colluvium, which is measured with respect to the bottom of the colluvium. Flow in the silt layers of the varved clay is written in terms of the pressure head in each silt layer $\varphi_{\mathrm{S}}[\mathrm{L}]$. Flow out of the fissure in the direction of the fissure normal to the plane of flow is written in terms of the water level in the fissure $h_{\mathrm{f}}[\mathrm{L}]$, measured with respect to the bottom of the fissure.

\subsection{Colluvium layer}

The colluvium layer is an unconfined aquifer. Water level variations are the result of variations in the groundwater recharge. The water level drops as water flows out into the fissure. Only saturated flow is simulated in the colluvium. The head in the colluvium, $h_{\mathrm{c}}$, is governed by the Boussinesq equation with areal recharge (e.g., Bear, 1972).

$$
\frac{\partial h_{\mathrm{c}}}{\partial t}=\frac{k_{\mathrm{c}}}{S_{\mathrm{y}}} \frac{\partial}{\partial x}\left(h_{\mathrm{c}} \frac{\partial h_{\mathrm{c}}}{\partial x}\right)+\frac{N}{S_{\mathrm{y}}}
$$

where $k_{\mathrm{c}}\left[\mathrm{L} \mathrm{T}^{-1}\right]$ is the hydraulic conductivity of the colluvium, $S_{\mathrm{y}}[-]$ is the specific yield of the colluvium, $N\left[\mathrm{~L} \mathrm{~T}^{-1}\right]$ is the areal recharge, and $t[\mathrm{~T}]$ is time.

The recharge $N$ is defined as the gross precipitation minus evaporation as discussed in the next section. Boundary conditions are that the head at $x=0$ is equal to the head in the fissure, and that the boundary at $x=L$ (halfway between two fissures) is a no-flow boundary because of symmetry

$$
\begin{aligned}
& h_{\mathrm{c}}(x=0)=\max \left(h_{\mathrm{f}, \mathrm{c}}, 0\right) \\
& \frac{\partial h_{\mathrm{c}}}{\partial x}(x=L)=0
\end{aligned}
$$

where $h_{\mathrm{f}, \mathrm{c}}$ is the water level in the fissure relative to the varved clays-colluvium interface; when the water level in the fissure drops below the bottom of the colluvium, the head at the boundary is set to zero. Equation (1), subject to boundary conditions of Eq. (2), is solved using a standard implicit finite difference approach (for details see Van der Spek, 2011). A dynamic equilibrium is used as initial condition.

\subsection{Varved clays}

Water infiltrates in the horizontal direction from the fissure into the silt layers, or drains from the silt layers into the fissure, depending on the head gradient. Flow in each silt layer is modeled as one-dimensional flow independent of the other silt layers. The head $h_{\mathrm{s}}$ in the silt layers is measured with respect to the bottom of the colluvium/top of the varved clays. When the silt is saturated, the pressure head in the silt layers, $\varphi_{\mathrm{s}}$, is governed by the one-dimensional diffusion equation (e.g., Bear, 1972)

$$
\frac{\partial \varphi_{\mathrm{s}}}{\partial t}=\frac{k_{\mathrm{s}}}{S_{\mathrm{s}}} \frac{\partial^{2} \varphi_{\mathrm{s}}}{\partial x^{2}}
$$

where $k_{\mathrm{S}}\left[\mathrm{L} \mathrm{T}^{-1}\right]$ is the saturated hydraulic conductivity of the silt and $S_{\mathrm{s}}[1 / \mathrm{L}]$ is the specific storage of the silt.

When the silt is not saturated, the water content changes in time and in space. The water content and the pressure head are governed by the one-dimensional Richards equation

$C \frac{\partial \varphi_{\mathrm{s}}}{\partial t}=\frac{\partial}{\partial x}\left(K_{\mathrm{s}}\left(\varphi_{\mathrm{s}}\right) \frac{\partial \varphi_{\mathrm{s}}}{\partial x}\right)$

where $C=\partial \theta / \partial \varphi_{\mathrm{s}}[1 / \mathrm{L}]$ is the moisture capacity, $\theta[-]$ is the water content, and $K_{\mathrm{s}}\left(\varphi_{\mathrm{s}}\right)\left[\mathrm{L} \mathrm{T}^{-1}\right]$ is the hydraulic conductivity of silt as a function of $\varphi_{\mathrm{s}}$. The unsaturated hydraulic conductivity and moisture content are represented by the the Mualem-Van Genuchten model (Van Genuchten, 1980). The boundary conditions are the same as for the colluvium, but now written in terms of pressure head

$$
\begin{aligned}
& \varphi_{\mathrm{S}}(x=0)=\max \left(\varphi_{\mathrm{f}, z},-1\right) \\
& \frac{\partial \varphi_{\mathrm{s}}}{\partial x}(x=L)=0
\end{aligned}
$$

where $\varphi_{\mathrm{f}, z}$ is the pressure head in the fissure at elevation $z$ [L]. The pressure head $\varphi_{\mathrm{f}, z}$ decreases linearly to a minimum of $-1 \mathrm{~m}$ at $1 \mathrm{~m}$ above the water level in the fissure, which represents that the moisture content never drops below field capacity. Flow in the silt layers is again solved numerically using a standard implicit finite difference scheme. The varved clays are discretized into fifty model layers; $\varphi_{\mathrm{s}}(x, t)$ differs in each model layer. Fifty percent of each model layer represents silt and fifty percent represents clay. This value is based on the observations of Huff (1989), who reports silt to clay ratios between 0.23 and 1.4. As for the colluvium, a dynamic equilibrium is used as initial condition.

\subsection{Fissures}

The water level in the fissure is calculated by means of a water balance. There are three components: inflow from the colluvium $\left(Q_{\mathrm{c}}\right)$, inflow into the varved clays $\left(Q_{\mathrm{v}}\right)$, and outflow in the longitudinal direction of the fissure $\left(Q_{\mathrm{f}}\right) ; Q_{\mathrm{v}}$ is negative for outflow from the varved clays into the fissure. The water balance for the fissure is written as

$\frac{w}{2} \frac{\mathrm{d} h_{\mathrm{f}}}{\mathrm{d} t}=Q_{\mathrm{c}}-Q_{\mathrm{v}}-Q_{\mathrm{f}}$

where $w[\mathrm{~L}]$ is the width of the fissure. The water balance is solved numerically (using a constant time step) in three steps. First, the water level in the fissure resulting from inflow from the colluvium is calculated simultaneously with the water level in the colluvium. Second, the new water level in the fissure is used as a boundary condition for calculating the pressure head in the varved clays. The pressure head in the varved clays is used to compute the inflow from the varved clays into the fissure $\left(Q_{\mathrm{v}}\right)$ and the head in the fissure is adjusted accordingly. Third, the longitudinal outflow from the fissure $\left(Q_{\mathrm{f}}\right)$ is simulated with a linear reservoir function

$Q_{\mathrm{f}}=\frac{w}{2 K} h_{\mathrm{f}}$ 
where $K[\mathrm{~T}]$ is the reservoir coefficient, and the head in the fissure is updated accordingly.

\section{Model evaluation}

Mean yearly precipitation in the Trièves region is $1050 \mathrm{~mm} \mathrm{yr}^{-1}$ as measured by MeteoFrance in Monestier de Clermont in the period 1948-2005. Average daily precipitation ranges from $2 \mathrm{~mm} \mathrm{day}^{-1}$ in July to almost $3.5 \mathrm{~mm}$ day $^{-1}$ in November. Monthly evaporation is approximated using the Thornthwaite equation (Thornthwaite, 1948) and a sine curve is fit to obtain daily values. Actual evaporation is approximated as $75 \%$ of potential evaporation for summer conditions and potential evaporation in winter conditions.

In this section, model behavior is explored using rainfall and evaporation data from 1958, which is representative for the 1948-2005 period. The model was run until an equilibrium situation was reached, where the total yearly recharge equals the total yearly outflow from the fissure, and the head variation in the colluvium and clays is the same from year to year.

\subsection{Dynamic equilibrium 1958}

The dynamic equilibrium for the large system is shown in Fig. 3. In the upper graph, the net recharge of 1958 is shown with bars (left vertical axis), and the simulated water level in the fissure is shown with a red line (right vertical axis). In the lower graph the variation of the outflow from the colluvium $\left(Q_{\mathrm{c}}\right)$, the inflow from the fissure into the varved clays $\left(Q_{\mathrm{v}}\right)$, and the outflow from the fissure $\left(Q_{\mathrm{f}}\right)$ are shown; when $Q_{\mathrm{v}}$ is negative water flows from the varved clays into the fissure. The total inflow into the varved clays is equal to the total outflow from the varved clays, and constitutes $7.6 \%$ of the total outflow from the colluvium.

\subsection{Dynamics of individual systems}

The dynamics of the colluvium and the saturated portion of the varved clays are well understood. Under saturated conditions, head variations in the varved clays are governed by Eq. (3). Head variations in the varved clays are controlled by the head fluctuation in the fissure. The magnitude of the fluctuation diminishes with distance from the fissure. Damping of the fluctuation as compared to the fluctuation in the fissure and the phase shift are a function of dimensionless parameter $\beta_{\mathrm{v}}$, defined as

$$
\beta_{\mathrm{v}}=\frac{k_{\mathrm{s}} T}{S_{\mathrm{s}} L^{2}}
$$

where $T$ is the period of the fluctuation. When $\beta_{\mathrm{v}}$ decreases, the damping and phase shift increase (e.g., Haitjema, 1995). Consider, for example, the case where the saturated hydraulic conductivity of the varved clays is decreased tenfold. The head variation at the bottom of the varved clays (which is
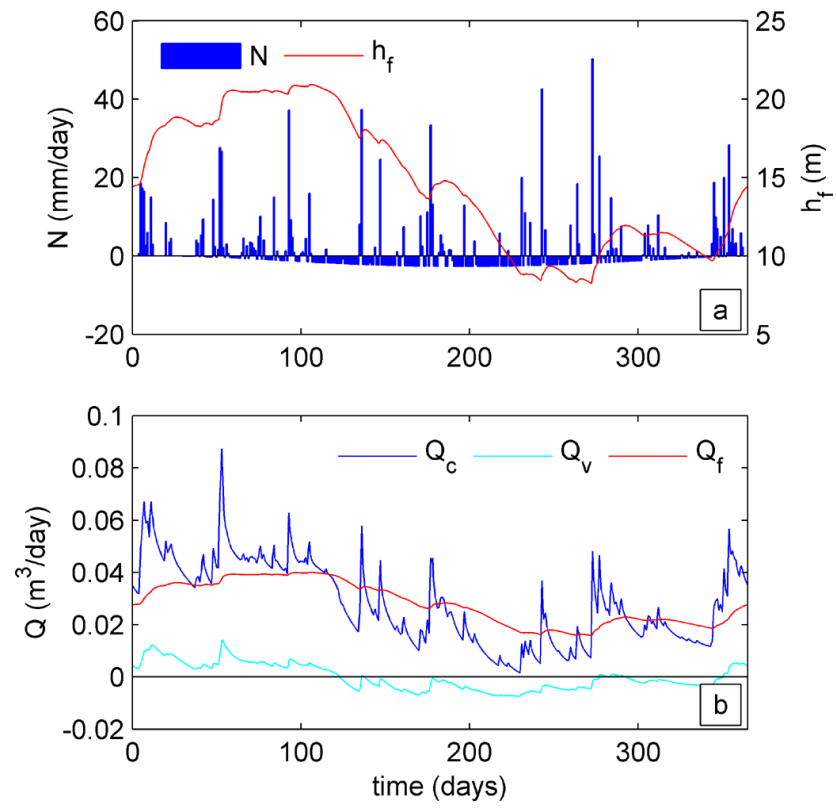

Fig. 3. Dynamic equilibrium of the large system for 1958. (a) Recharge $(N)$ and simulated water level in fissure $\left(h_{\mathrm{f}}\right.$, shown with respect to bottom of fissure). (b) Outflow from colluvium $\left(Q_{\mathrm{c}}\right)$, inflow from fissure into varved clays $\left(Q_{\mathrm{V}}\right)$, and outflow from fissure $\left(Q_{\mathrm{f}}\right)$.

always saturated) is plotted against time for the large system for the year 1958 in Fig. 4. Fluctuations of the water level in the fissure damp out quicker when the hydraulic conductivity is smaller (dashed lines). Head variations in the colluvium react in a similar manner. In the colluvium, head variations are governed by Eq. (1) and the damping and phase shift are controlled by

$\beta_{\mathrm{c}}=\frac{k_{\mathrm{c}} \overline{h_{\mathrm{c}}} T}{S_{\mathrm{y}} L^{2}}$

where $\overline{h_{\mathrm{c}}}$ is an average head in the colluvium.

\subsection{Dynamics of entire system}

The behavior of the entire system is considered next. The fluctuation of the water level in the fissure, and hence the pressure variation in the varved clays, is an interplay of the three main processes: inflow from the colluvium, exchange with the varved clays, and longitudinal outflow from the fissure. Three factors are discussed here: the effect of the distance between two fissures, the effect of the model parameters of the fissure, and the effect of unsaturated conditions in the varved clays.

(1) The main effect of a larger distance between two fissures is a larger head halfway between the fissures $(x=L)$ and an increased outflow from the colluvium into the fissure. The increased flow into the fissure results in a higher water level in the fissure and higher heads in the varved clays. 


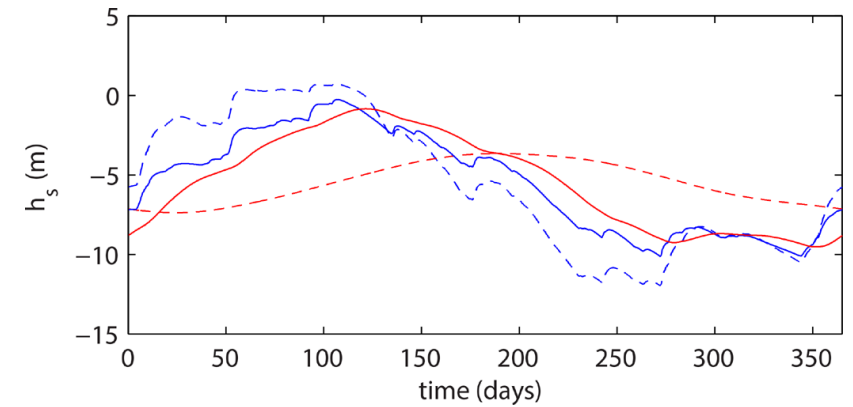

Fig. 4. The influence of the hydraulic conductivity of saturated silt on the head at the bottom of the varved clays during 1958 for $k_{\mathrm{S}}=$ $0.001 \mathrm{~m} \mathrm{day}^{-1}$ (dashed lines) and $k_{\mathrm{S}}=0.01 \mathrm{~m} \mathrm{day}^{-1}$ (solid lines) at the fissure ( $x=0$, blue lines) and halfway between two fissures ( $x=L$, red lines). Head variations are shown with respect to the bottom of the colluvium/top of the varved clays.

(2) The fissure hydrology is modeled as a linear reservoir (Eq. 7) and the water level in the fissure is computed with a water balance (Eq. 6). A smaller fissure width $w$ or a larger reservoir constant $K$ results in a larger water level in the fissure. These two parameters are correlated. Water level fluctuations in the fissure show more short-term variations when $w$ and $K$ are smaller.

(3) Not surprisingly, water pressure propagation in the varved clays is much slower when the varved clays become unsaturated near the fissure. There is always a significant amount of water in the fissure for the model of 1958 for either of the standard systems (Table 1). Model results indicate that the varved clays are always saturated at the bottom of the fissure; the water level in the fissure in the large system never drops below $8.2 \mathrm{~m}$. In the small system it never drops below $0.4 \mathrm{~m}$. The pressure head in the varved clays is contoured at the beginning of $1958(t=0)$ and at the moment when the water level in the fissure reaches a minimum in Fig. 5. In the large system, a relatively small part of the varved clays becomes unsaturated (negative pressure heads, Fig. 5b). Unsaturated flow occurs only close to the fissure in the upper part of the clays. In the small system, a large part of the varved clays is unsaturated at the moment of a minimum water level in the fissure (Fig. 5d). The influence of unsaturated flow is larger for the small system than for the large system.

\section{Application to landslides in the Trièves area}

Head measurements are available from three landslides in the Trièves area: La Mure, Avignonet and Monestier du Percy (Fig. 1). The measurements are very scattered, both temporally and spatially. Most measurement periods are relatively short and occur during or after increased landslide activity.

Parameter values for the varved clays were obtained from the literature. It is not always indicated in the literature how these values were determined, except for the saturated
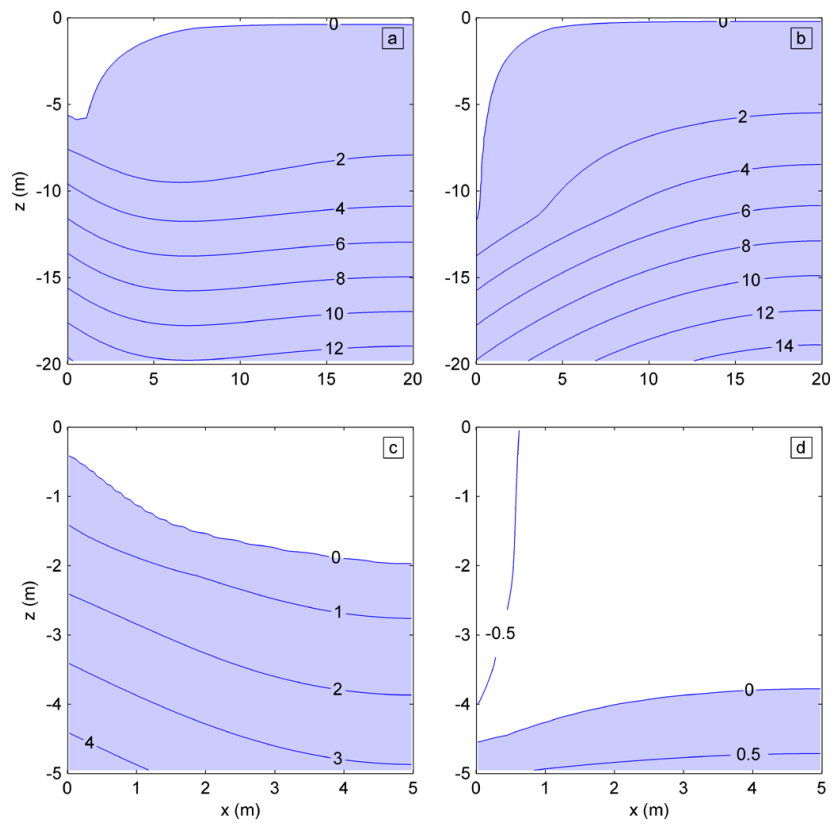

Fig. 5. Pressure head distribution in cross sections of varved clays. Width of each graph is half the distance between two fissures $(L)$, height is fissure depth $(d)$. Fissures are located at $x=0$. Blue area is saturated. (a) Large system at $t=0$ days, (b) large system at $t=$ 272 days, (c) small system at $t=0$ days, (d) small system at $t=230$ days.

hydraulic conductivity of silt, which was determined with laboratory and field experiments by a number of authors (Table 2). Parameters for the colluvium and fissures are not available and were determined through calibration to the data of the three landslides in the Trièves area. Model initiation was done using the 1958 precipitation and evaporation data.

Data on the local settings of the measurement locations is not available. The fissure distance and depth at the measurement locations are not known. Therefore, for each case the most appropriate standard system (Table 1) was used. In addition, the distance between the observation wells and the fissures is not known. Heads were simulated at the fissure $(x=0)$ and halfway between two fissures $(x=L)$ to capture the range of groundwater dynamics. An expert-driven calibration was performed as the available data does not justify a formal best-fit approach.

The parameters of the model and their values are given in Table 2. The large range for the specific yield of the colluvium may have several reasons. First, what is called the colluvium here may contain parts of alluvial or morainic origin, which have different properties (Van Asch et al., 2009). Second, the specific yield may be influenced by the presence of a number of (small) fissures in the colluvium. As mentioned, the parameters for the varved clays were not included in the calibration. The values of the hydraulic conductivity and specific storage of silt have a large influence on the pore water pressures in the varved clays, especially at a large distance 
Table 2. Model parameters.

\begin{tabular}{|c|c|c|c|}
\hline Parameter & Description & Value & Reference \\
\hline \multicolumn{4}{|c|}{ Silt layers in varved clays } \\
\hline$k_{\mathrm{S}}$ & $\begin{array}{l}\text { Saturated hydraulic } \\
\text { conductivity }\end{array}$ & $0.001\left(\mathrm{~m} \mathrm{day}^{-1}\right)$ & $\begin{array}{l}\text { Van Asch et al. (1996), Van Genuchten (1989) } \\
\text { and Vuillermet et al. (1994) }\end{array}$ \\
\hline$S_{\mathrm{S}}$ & Specific storage & $0.001\left(\mathrm{~m}^{-1}\right)$ & $\begin{array}{l}\text { Nieuwenhuis }(1991): k / S_{\mathrm{S}}=10.2 \mathrm{~m}^{2} \mathrm{day}^{-1} \\
\text { with } k=10^{-2} \mathrm{~m} \mathrm{day}^{-1}\end{array}$ \\
\hline$n_{\mathrm{p}}$ & Porosity & $0.45(-)$ & Nieuwenhuis (1991) \\
\hline$\alpha$ & Van Genuchten parameter & $0.28\left(\mathrm{~m}^{-1}\right)$ & From pF curve in Nieuwenhuis (1991) \\
\hline$n$ & Van Genuchten parameter & $1.16(-)$ & From pF curve in Nieuwenhuis (1991) \\
\hline \multicolumn{4}{|l|}{ Colluvium } \\
\hline$k_{\mathrm{c}}$ & Hydraulic conductivity & $0.1\left(\mathrm{~m} \mathrm{day}^{-1}\right)$ & Calibrated \\
\hline$S_{\mathrm{y}}$ & Specific yield & $0.1-0.3(-)$ & Calibrated \\
\hline \multicolumn{4}{|l|}{ Fissure } \\
\hline$w$ & Width & $0.1(\mathrm{~m})$ & Calibrated \\
\hline$K$ & Reservoir coefficient & 5-28 (days) & Calibrated \\
\hline
\end{tabular}

from the fissures (Eq. 8 and Fig. 4). Information on the distance between the fissures and measurement locations are required to determine these two parameters more accurately. Their influence on the head in the colluvium is very small. Therefore, where measurements of the head in the colluvium are available, the hydraulic conductivity and specific yield of the colluvium may be calibrated partly independently of the values of the hydraulic conductivity and specific storage of silt. The influence of the porosity and the Van Genuchten parameters on the system as a whole is small, as these parameters only influence the groundwater dynamics in the unsaturated part of the varved clays.

Heads were measured during three periods at the Avignonet landslide. From July 1985 until January 1987 the head was measured in fourteen piezometers at different locations and depths ranging from 4.5 to $30 \mathrm{~m}$ below ground surface, penetrating both colluvium and varved clays (Blanchet, 1988). From January 2004 until September 2005 the head was measured in two piezometers: one in the colluvium and one in the varved clays, at a depth of $43 \mathrm{~m}$. From July until September 2008 the head was measured in two piezometers: one at a depth of $5 \mathrm{~m}$ and one at a depth of $47 \mathrm{~m}$ (Bièvre et al., 2012). The piezometers deeper than $20 \mathrm{~m}$ are located below the maximum fissure depth used in this study, and therefore not included in the calibration. The Avignonet landslide has a thickness of 4-5 $\mathrm{m}$ and slip surfaces at different depths: a few meters, 10-17 m, and 42-47 m (Jongmans et al., 2008). This means that the situation of this landslide may be comparable to either of the standard systems of Table 1 . The small standard system gave the best results for the first monitoring period. The large standard system gave the best results for the other two monitoring periods. Results are shown in Fig. 6. The top row of graphs represents the recharge during the monitoring periods; the second row of graphs represents the head variation in the colluvium; the third row of graphs represents the head variation in the varved clays. Measurements in the fourteen piezometers of the first monitoring period are summarized by the grey area in the first column of graphs in Fig. 6, spanning the minimum and maximum recorded heads; no clear distinction was observed between measurements that were taken in the colluvium or the varved clays. For the second and third monitoring periods, measured heads are compared only to measurements in the colluvium (black dots and black dashed line).

The heads in the colluvium in the La Mure landslide were measured in two piezometers from 9 March until 8 May 1986 (Van Genuchten, 1989). The heads in the varved clays were measured in four piezometers at different locations and depths from 12 March until 7 May 1987 (Van Genuchten, 1989). The thickness of the colluvium in La Mure is $0.5-1 \mathrm{~m}$. The slip surface in the landslide is located at $4-6 \mathrm{~m}$ below ground surface (Nieuwenhuis, 1991). The standard system with small fissure distance and depth is most similar to this situation. Results are shown in Fig. 7a and b.

The heads in the varved clays of the Monestier du Percy landslide were measured from January 1993 until December 1996. The measured heads vary between 4.5 and $6.5 \mathrm{~m}$ below the ground surface. These variations are relatively small and shallow. The standard system with small fissure distance and depth gives the best results for this case. Results are shown in Fig. 7c. The measured and calculated fluctuations are similar, but the peaks in head do not always coincide. In the measured heads, peaks are seen in AprilMay preceded by periods with a relatively low head during January-March. This is believed to be a consequence of the fact that a part of the precipitation falls as snow and melts in spring. Snow cover is common at altitudes of 700-800 $\mathrm{m}$ in this region in winter. Surface runoff may flow directly into the fissures during this period. Moreover, it has to be mentioned that a drainage system was installed on the landslide 

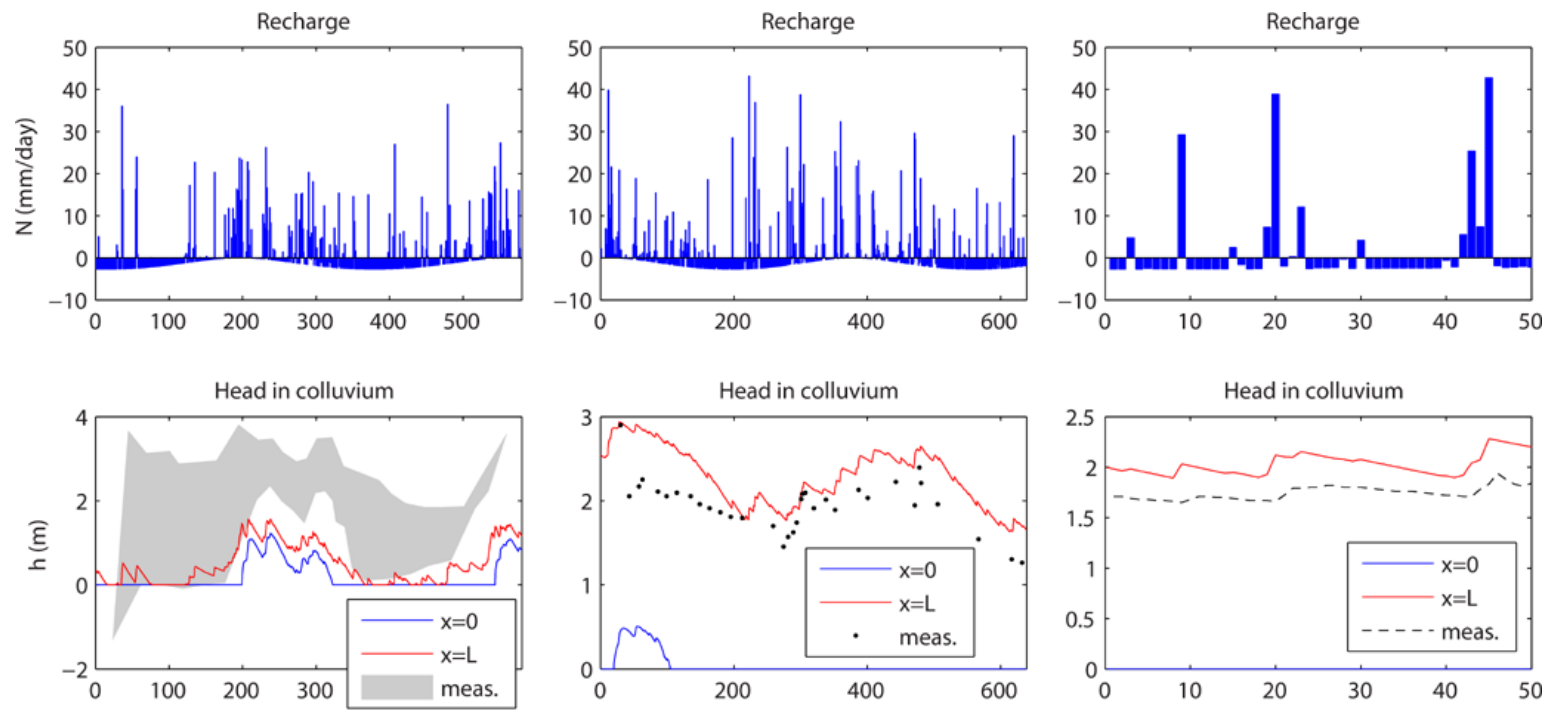

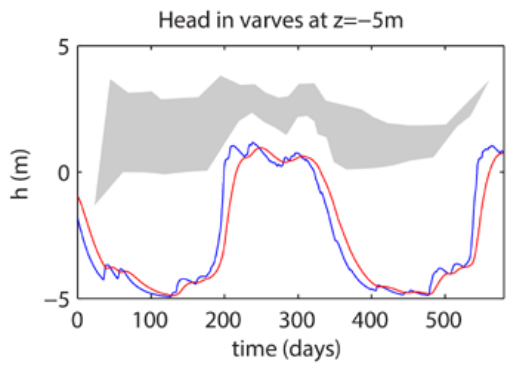

(a)

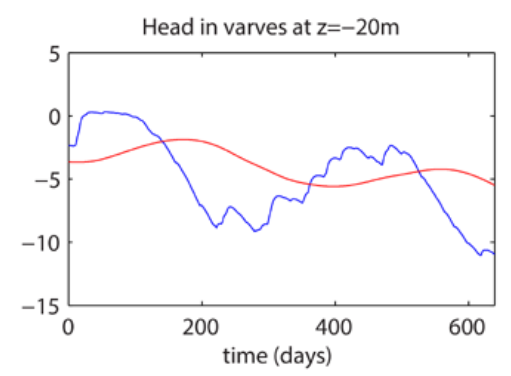

(b)

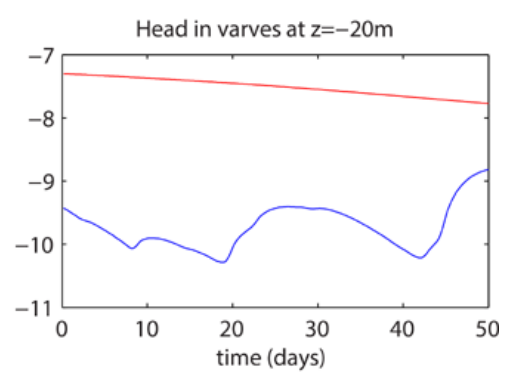

(c)

Fig. 6. Recharge (first row), measured and simulated heads for the colluvium (second row) and varved clays (third row) for the Avignonet landslide during three monitoring periods. (a) July 1985-January 1987, (b) January 2004-September 2005, (c) July 2008-September 2008 . Head variations are shown with respect to the bottom of the colluvium/top of the varved clays.

in 1979 (Van Asch et al., 2009), which may influence the measured head and cause a difference between the measured and calculated head. Also permeable alluvial deposits that are present above the main scarp influence the groundwater system (Van Asch et al., 2009).

For all cases studied, good results are obtained for the colluvium, as measured values fall between the head variation at $x=0$ (blue lines) and $x=L$ (red lines). It is more difficult to obtain a good match in the varved clays. This is partly due to a lack of information, especially the depths of the fissures and the distances between the fissures and the monitoring locations. The calibration of Monestier du Percy indicates that snow and snowmelt may influence the fluctuations of the head in the varved clays. Furthermore, variations of the head measured in open standpipes may show a delayed response caused by the low hydraulic conductivity of the varved clays (e.g., Van Asch et al., 2009). Nonetheless, the measured and simulated heads show significant similarities.

\section{Groundwater dynamics compared to landslide activity 1959-2004}

Groundwater dynamics are simulated for the period from 1959 to 2004. Data on landslide activity in the Trièves region are compared to simulated groundwater dynamics; long-term groundwater records are not available for such a comparison. The model was run with the daily precipitation data of Monestier de Clermont from 1956 to 2004. The first three years are used for model initiation.

\subsection{Groundwater dynamics}

Results for the large system are shown in Fig. 8. The graphs in Fig. 8 represent, from top to bottom, the yearly precipitation, the head variation in the colluvium, and the head variation at the bottom of the varved clays $(z=-20 \mathrm{~m})$; all head variations are shown at $x=0 \mathrm{~m}$ and $x=L$ and are given with respect to the bottom of the colluvium. In the colluvium, the head varies from $h=0 \mathrm{~m}$ to above $4 \mathrm{~m}$ and regularly drops to $h=0 \mathrm{~m}$ at $x=0 \mathrm{~m}$, which means that the water level in the fissure is below the bottom of the colluvium. Simulated 

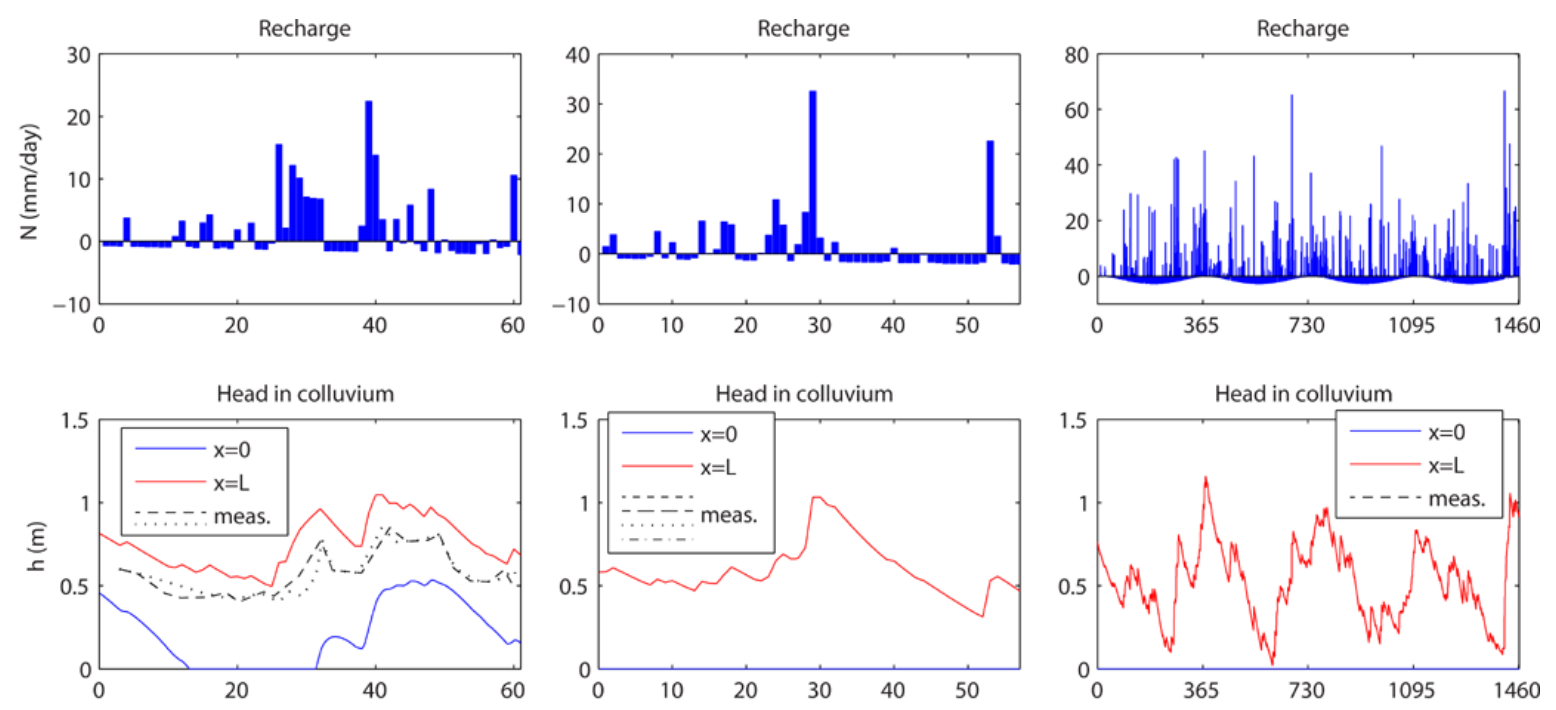

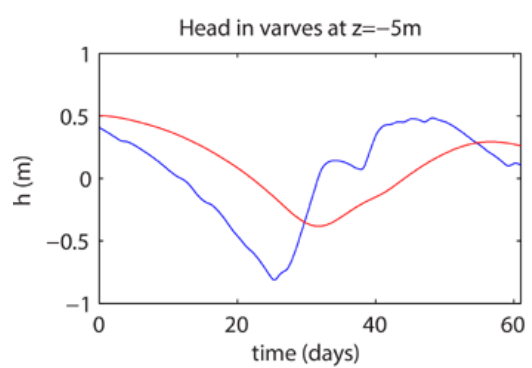

(a)

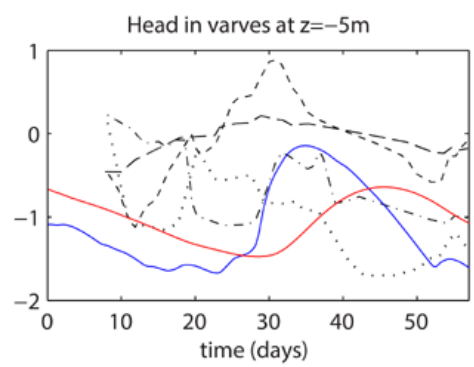

(b)

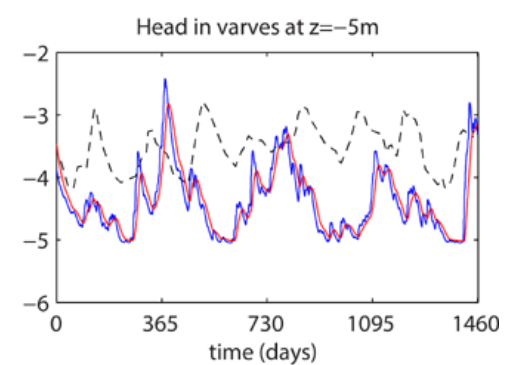

(c)

Fig. 7. Recharge (first row), measured and simulated heads for the colluvium (second row) and varved clays (third row) for the La Mure and Monestier du Percy landslides. (a) La Mure, 9 March 1986-8 May 1986, (b) La Mure, 12 March 1987-7 May 1987, (c) Monestier du Percy, 1993-1996. Head variations are shown with respect to the bottom of the colluvium/top of the varved clays.

head variations at the bottom of the varved clays are large. At $x=0 \mathrm{~m}$ the head varies up to $20 \mathrm{~m}$, while at $x=L$ the head still varies more than $10 \mathrm{~m}$.

\subsection{Comparison to recorded landslide activity}

Increased pore water pressure on the slip surface of a landslide results in a stability reduction. High landslide activity is expected to coincide with very high heads in the varved clays. Data on landslide activity in the Trièves region is compared to the simulated groundwater dynamics of Fig. 8. The dates of several landslides in the Trièves are recorded in the landslide database of BRGM (2011). The landslides were selected while movements labeled as "mud-debris flow", "collapse", and "stream erosion" were not considered. Most of the records have a dating accuracy of approximately 1 month. The date of occurrence is known with an accuracy of approximately one day for 19 landslides. but specific local circumstances are not known. Therefore, only a qualitative comparison is justified.

Most landslides in the Trièves start to move between February and April. Annual peaks in the simulated heads in the varved clays occur in these same months (Fig. 8). The magnitude of the simulated head is, however, not the only trigger, as high heads of the same or higher magnitude are also simulated in other years in which no significant landslide activity was recorded. This indicates that specific local circumstances are important to triggering a landslide. Interestingly, the model results show clear cycles of wetter and drier years, resulting in higher and lower heads in the system. These trends, however, do not emerge from the database of landslide occurrence in the Trièves.

A few landslide reactivations were published with more details. There appears to be a clear correlation between the simulated heads of Fig. 8 and reported occurrence of landslide reactivation. In April 1978, the Monestier du Percy landslide was reactivated (Van Asch et al., 2009). The simulated heads in this month are very high; higher heads are simulated only for 1970 and 1995. In March 1981 the velocity of the Harmalière landslide increased dramatically and part of the landslide changed into a mudflow (Giraud et al., 1991; Jongmans et al., 2008, 2009). The same happened to the landslide of La Salle en Beaumont in January 1994. Another earth flow occurred in January 2001 at L'Adverseil. These extreme events coincide with periods when the simulated heads are highest. The simulated heads for the years in 

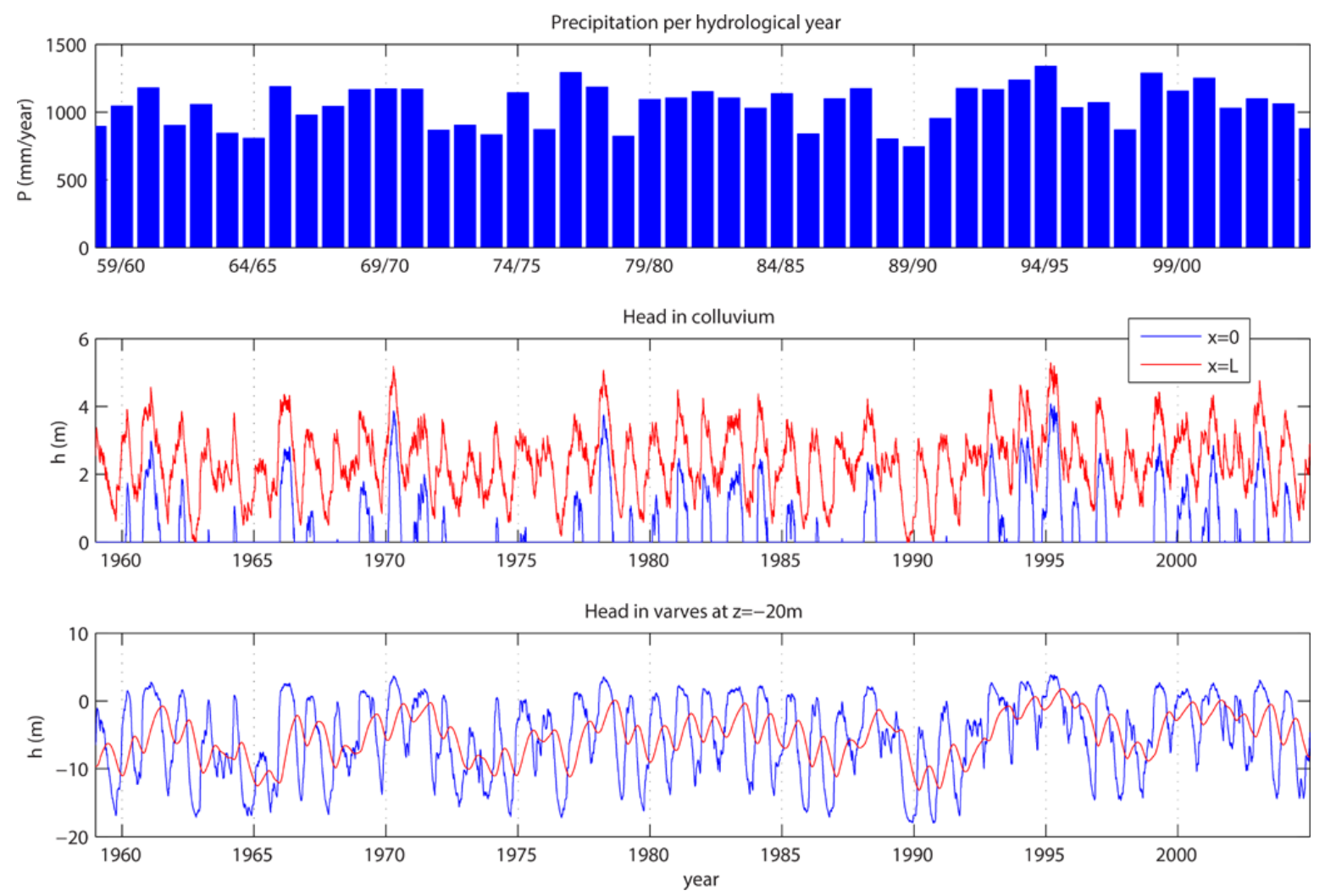

Fig. 8. Total precipitation per hydrological year (1 September-31 August) and calculated head for large standard system for 1959-2004. The head is plotted for $x=0 \mathrm{~m}$ (next to fissure) and $x=L \mathrm{~m}$ (halfway between two fissures). Head variations are shown with respect to the bottom of the colluvium/top of the varved clays.

which these events occurred are relatively high compared to those for other years, although heads of the same magnitude or higher also occur at other times. Clearly, higher quality landslide data is required for a more in-depth analysis.

\section{Discussion}

The presented conceptual model is based on a number of approximations. Three issues are discussed here. First, the conceptual model presented here is compared to alternative model approaches. Second, the processes causing a timevarying fissure width and their possible effects on groundwater dynamics are described. Third, the possibility of air entrapment in silt layers is discussed.

\subsection{Model approach}

Van Asch et al. (1996) describe a conceptual hydrological model equivalent to the model used in this research, but use different equations to represent the groundwater dynamics. They use a combined linear reservoirs model to simulate the water fluctuations in the colluvium and fissures and use an approximate formula for infiltration into the varved clays rather than formally solving the Richards equation. One of their conclusions is that the mean annual residence time of water in the fissures is not sufficient to fully saturate the varved clays each year. This is based on the assumption that the varved clays are unsaturated (pressure head between -1.5 and $-0.5 \mathrm{~m}$ and associated degree of saturation of approximately 0.9 ) before a rise in head in the fissure occurs. Simulations of the two standard cases in this paper show that the silt layers at the bottom part of the fissure are always saturated during an average year. Assuming that the fissures reach the slip surface, this means that the pore water pressure at the slip surface is determined by water pressure propagation in saturated soil, which is a faster process than saturation. Not only the head in the fissures, but also the head in the varved clays varies considerably and may influence the stability of the landslide. The extent to which the variations are damped and delayed depends on the distance from the fissures. It is noted, however, that it is not demonstrated that the model used in this paper results in a better match with the measured groundwater dynamics than the model of Van Asch et al. (1996). Such a judgment can only be made with additional measurements of the head at the bottom of the varved clays.

The slip surface is not conceptualized as a preferential flow path in this study. Nieuwenhuis (1991), Van Asch et 
al. (1996) and Vuillermet et al. (1994) assume infiltration into the silt laminae of the varved clays rather than preferential flow along the slip surface. Preferential flow may be modeled by an increased permeability of the varved clays around the slip surface. Equation (8) and the sensitivity analysis in Fig. 4 show that this results in a faster pore water pressure response in the varved clays and hence on the slip surface.

\subsection{Fissure geometry and time-varying fissure width}

Fissures are a crucial part of the conceptual model, as they constitute the connection between the colluvium and the varved clays (e.g., Nieuwenhuis, 1991; Vuillermet et al., 1994; Van Asch et al., 1996; Bièvre et al., 2012). In this study, longitudinal drainage from the fissure is a function of the water level in the fissure only, not of the water levels in the remainder of the fissure network. Head fluctuations in the fissures are the result of fluctuating precipitation and evaporation during the year, water exchange with the varved clays, and drainage from the fissure.

Nieuwenhuis (1991) reports a dynamically changing fissure width at the La Mure landslide. He describes how water collects in channels above the fissures at the downslope edge of the landslide, which results in increased infiltration time for water to reach the slip surface. The stability of the downslope part of the landslide decreases due to the increased pore water pressure. New fissures develop between the moving and stagnant parts of the landslide, or existing fissures open up to the slip surface. Water can reach the slip surface via these fissures. In this way the instability of the landslide develops retrogressively, in an upslope direction. In this paper, the width of the fissure is constant through time. A timevarying fissure width may be required in case of highly dynamic interactions between fissure geometry and mass movement, as system behavior is very sensitive to the width of the fissure.

\subsection{Air entrapment in silt layers}

Air entrapment is neglected in most water infiltration models but it can be important (Stadler et al., 2012). Air entrapment in thin silt layers is not included in the model presented in this paper. Vuillermet et al. (1994) performed a field experiment to measure the horizontal infiltration rate in varved clays. When water infiltrates, air may get trapped in unsaturated silt layers, which are confined between two clay layers. Pneumatic pressures develop at the infiltration fronts and inhibit the horizontal infiltration. Air may only escape through the infiltrating water, which is a slow process. In the model presented here, the water pressure propagation in the silt layer at the slip surface is not directly influenced by air entrapment, as the bottom of the varved clays is always saturated. There is an indirect effect, however, as air entrapment of silt layers may slow down infiltration from the fissure, which in turn means that the fissure fills up quicker.

\section{Conclusions}

In this research the hydrogeology of landslides in varved clays is conceptualized as follows. The varved clays and the colluvium are two subsystems, which are connected by vertical fissures. Precipitation infiltrates into the colluvium and results in a perched water table in this layer. Outflow from the colluvium enters the fissure. Water infiltrates horizontally from the fissure into the silt layers of the varved clays, resulting in a pressure rise. When the water level in the fissure drops, water drains from the varved clays to the fissure. The system drains in the downslope direction by a network of connected fissures.

The conceptual model is translated into a mathematical model to simulate the groundwater dynamics in landslides in varved clays. The colluvium is modeled as an unconfined aquifer. The silt layers in the varved clays are modeled as separate, thin, confined layers. The head in the fissure acts as a boundary condition for both subsystems. The finite difference method is used to compute the head in the colluvium and varved clays. The water level in the fissure is computed by means of a water balance.

Simulated heads were compared to measured heads from three landslides in the Trièves area. The simulated heads in the colluvium are similar to the measured heads for all cases considered. The simulated and measured heads in the varved clays do not match as well, but the general patterns show reasonable resemblance. It is difficult to obtain a good match in the varved clays as the distance between the observation well and the fissure and the distance between fissures are not known for any of the monitoring locations. The good match in the colluvium and reasonable match in the varved clays are evidence that the most important hydrological mechanisms are included in the model, especially when considering the limitations of the available data.

The fissure geometry plays a major role in the hydrological system of the varved clays in the Trièves region. Measurement of the width and depth of the fissures and the distance between the fissures are needed to improve the accuracy of the model simulations for specific locations. Geophysical methods can be used to determine the fissure geometry (Bièvre et al., 2012). Measurement of the width of the fissures at different moments during a year may elucidate the effect of changing fissure conditions, as discussed by Nieuwenhuis (1991).

Analysis of the model results leads to increased insight into the most important factors affecting the groundwater dynamics in varved clay landslides. Both the width and the reservoir coefficient of the fissure have a large effect on the magnitude of the head in the fissure and the varved clays. Changes in fissure width during slope deformation may affect the pressure development in the varved clays. The head variation in the fissure is a boundary condition for the head variation in the varved clays. The (unsaturated) hydraulic conductivity and specific storage of the silt layers affect the 
extent to which the head variation in the varved clays is delayed and damped. A proper estimation of the values of these parameters is important in simulating the pressure distribution and hence in assessing the stability of the landslide. Model simulations for the period 1959-2004 indicate that the heads are largest during the first months of the year. Landslide activity is generally largest during the same months. The effect of wet and dry years is visible in the model results. A combination of the hydrological model with slope stability and slope displacement analyses may provide further insight in the effects of groundwater dynamics on landslide activity.

Acknowledgements. We thank Jean-Philippe Malet, Denis Jongmans, Theo van Asch, Ulrich Kniess, and Gregory Bièvre for insightful discussions about the Trièves landslides and for providing the field data. We thank three anonymous reviewers for their constructive comments.

Edited by: R. Greco

\section{References}

Bear, J.: Dynamics of fluids in porous media, Dover Publications, NY, 1972.

Bièvre, G., Jongmans, D., Winiarski, T., and Zumbo, V.: Application of geophysical measurements for assessing the role of fissures in water infiltration within a clay landslide (Trièves area, French Alps), Hydrol. Process., 26, 2128-2142, doi:10.1002/hyp.7986, 2012.

Blanchet, F.: Etude geomechanique de glissements de terrain dans les argiles glaciolacustres de la vallee du Drac, Ph. D. thesis, UJF Grenoble, 1988.

Bogaard, T. A., Malet, J.-P., and Schmittbuhl, J.: Hydrological behaviour of unstable clay-shales slopes: the value of crossdisciplinary and multitechnological research at different scales, Hydrol. Process., 26, 2067-2070, doi:10.1002/hyp.9454, 2012.

BRGM: Base de Données Nationale Mouvements de Terrain, available at: http://www.bdmvt.net/ (last access: 15 November 2012), 2011.

Buma, J. and Dehn, M.: A method for predicting the impact of climate change on slope stability, Environ. Geol., 2-3, 190-196, 1998.

Giraud, A.: Les argiles litées glacio-lacustres du Trièves (France), Deuxièmes entretiens du centre Jacques Cartier, Colloque no 14 genie civil: risques naturels 69, 1988.

Giraud, A., Gourc, J. P., Besson, L., and Fabre, D.: Approche pluridisciplinaire des problèmes posés par un glissement de terrain sur faible pente, Rev. Fr. Géotechnique, 14, 57-66, 1980.

Giraud, A., Antoine, P., van Asch, T. W. J., and Nieuwenhuis, J. P.: Geotechnical problems caused by glaciolacustrine clays in the French Alps, Eng. Geol., 31, 185-195, 1991.

Haitjema, H. M.: Analytic Element Modeling of Groundwater Flow, Academic press, San Diego, CA, 1995.

Huff, W. D.: Pleistocene varved clays and related sediments Lac du Trièves, Drac valley, south eastern France, Géologie Alpine, 65, 75-104, 1989.
Iverson, R. M.: Landslide triggering by rain infiltration, Water Resour. Res., 36, 1897-1910, 2000.

Jongmans, D., Renalier, F., Kniess, U., Schwartz, S., Pathier, E., Orengo, Y., Bièvre, G., Villemin, T., and Delacourt, C.: Characterization of the Avignonet landslide (French Alps) using seismic techniques, in: Landslides and Engineered Slopes - 10th International Symposium On Landslides And Engineered Slopes, Xi'an, China, 2008.

Jongmans, D., Bièvre, G., Renalier, F., Schwartz, S, Beaurez, N., and Orengo, Y.: Geophysical investigation of a large landslide in glaciolacustrine clays in the Trièves area (French Alps), Eng. Geol., 109, 45-56, 2009.

Krzeminska, D. M., Bogaard, T. A., van Asch, Th. W. J., and van Beek, L. P. H.: A conceptual model of the hydrological influence of fissures on landslide activity, Hydrol. Earth Syst. Sci., 16, 1561-1576, doi:10.5194/hess-16-1561-2012, 2012.

Lindenmaier, F., Zehe, E., Dittfurth, A., and Ihringer, J.: Process identification at a slow-moving landslide in the Vorarlberg Alps, Hydrol. Process., 19, 1635-1651, 2005.

Malet, J.-P., van Asch, Th. W. J., van Beek, R., and Maquaire, O.: Forecasting the behaviour of complex landslides with a spatially distributed hydrological model, Nat. Hazards Earth Syst. Sci., 5, 71-85, doi:10.5194/nhess-5-71-2005, 2005.

Nieuwenhuis, J. D.: Variations in stability and displacements of a shallow seasonal landslide in varved clays, $\mathrm{Ph}$. D. thesis, Utrecht University, 1991.

Reid, M. E. and Iverson, R. M.: Gravity-driven groundwater-flow and slope failure potential: 2. Effects of slope morphology, material properties, and hydraulic heterogeneity, Water Resour. Res., 28, 939-950, 1992.

Schulz, W. H., McKenna, J. P., Kibler, J. D., and Biavati, G.: Relations between hydrology and velocity of a continuously moving landslide: Evidence of pore-pressure feedback regulating landslide motion?, Landslides, 6, 181-190, 2009.

Stadler, L., Hinkelmann, R., and Helmig, R.: Modeling macroporous soils with a two-phase dual-permeability model, Transport Porous Med., 95, 585-601, doi:10.1007/s11242-012-00643, 2012.

Thornthwaite, C. W.: An approach toward a rational classification of climate, Geogr. Rev., 38, 55-94, doi:10.2307/210739, 1948.

Uchida, T., Kosugi, K., and Mizuyama, T.: Effects of pipeflow on hydrological process and its relation to landslide: a review of pipeflow studies in forested headwater catchments, Hydrol. Process., 15, 2151-2174, 2001.

van Asch, T. W. J., Hendriks, M. R., Hessel, R., and Rappange, F. E.: Hydrological triggering of landslides in varved clays in the French Alps, Eng. Geol., 42, 239-251, 1996.

van Asch, T. W. J., Malet, J.-P., van Beek, L. P. H., and Amitrano, D.: Techniques, issues and advances in numerical modelling of landslide hazard, B. Soc. Geol. Fr., 2, 65-88, 2007.

van Asch, Th. W. J., Malet, J.-P., and Bogaard, T. A.: The effect of groundwater fluctuations on the velocity pattern of slowmoving landslides, Nat. Hazards Earth Syst. Sci., 9, 739-749, doi:10.5194/nhess-9-739-2009, 2009.

van Beek, L. P. H.: The impact of land use and climatic change on slope stability in the Alcoy region, Spain, Netherlands Geographical Studies, Utrecht, 2002.

van Beek, L. P. H. and van Asch, T. W. J.: A combined conceptual model for the effects of fissure-induced infiltra- 
tion on slope stability, Lect. Notes Earth Sci., 78, 147-167, doi:10.1007/BFb0009724, 1999.

van der Spek, J. E.: Characterization of the groundwater dynamics in landslides in varved clays, M.Sc. thesis, Delft University of Technology, 2011.

van Genuchten, M. T.: A closed-form equation for predicting the hydraulic conductivity of unsaturated soils, Soil Sci. Soc. Am. J., 44, 892-898, 1980.

van Genuchten, P. M. B.: Movement mechanisms and slide velocity variations of landslides in varved clays in the French Alps, Ph. D. thesis, Utrecht University, 1989.

van Genuchten, P. M. B. and van Asch, T. W. J.: Factors controlling the movement of a landslide in varved clays near La Mure (French Alps), B. Soc. Geol. Fr., 3, 461-469, 1988. van Westen, C. J., van Asch, T. W. J., and Soeters, R.: Landslide hazard and risk zonation - Why is it still so difficult?, B. Eng. Geol Environ., 65, 167-184, doi:10.1007/s10064-005-0023-0, 2006.

Vuillermet, E., Cordary, D., and Giraud, A.: Caractéristiques hydrauliques des argiles litées du Trièves (Isère), Bulletin of the international association of engineering geology, B. Eng. Geol. Environ., 49, 85-90, doi:10.1007/BF02595004, 1994.

Wienhöfer, J., Lindenmaier, F., and Zehe, E.: Challenges in Understanding the Hydrologic Controls on the Mobility of Slow-Moving Landslides, Vadose Zone J., 10, 496-511, doi:10.2136/vzj2009.0182, 2010.

Wilkinson, P. L., Anderson, M. G., and Lloyd, D. M.: An integrated hydrological model for rain-induced landslide prediction, Earth Surf. Processes, 27, 1285-1297, 2002. 